\title{
Changes in the somatostatin, substance $P$ and vasoactive intestinal polypeptide content of the gastrointestinal tract following streptozotocin-induced diabetes in the rat
}

\author{
M. Ballmann and J. M. Conlon \\ Clinical Research Group for Gastrointestinal Endocrinology of the Max-Planck-Society at the University of Göttingen, Göttingen, FRG
}

\begin{abstract}
Summary. Rats with streptozotocin-induced diabetes of 10 weeks' duration showed significant changes in the total content of somatostatin, substance $P$ and vasoactive intestinal polypeptide in the stomach and small intestine compared with control animals. An increase $(p<0.05)$ in the concentration and total content of gastric somatostatin and a decrease $(p<$ $0.05)$ in the concentration and content of gastric substance $P$ were seen in the streptozotocin-treated rats. The increase in the vasoactive intestinal polypeptide (VIP) content $(54 \%, p<$ $0.05)$ and the decrease in the substance $\mathrm{P}$ content $(35 \%, p<$ 0.05 ) of the gut may contribute to the impaired intestinal mo-
\end{abstract}

tility observed in animals with experimentally produced diabetes. Both the diabetogenic effect of streptozotocin and the changes in regulatory peptide concentrations were prevented by injection of nicotinamide before streptozotocin suggesting that the changes did not arise from a non-specific toxic effect of streptozotocin upon gastrointestinal neurones and/or endocrine cells.

Key words: Somatostatin, substance $P$, vasoactive intestinal polypeptide, streptozotocin-diabetes, nicotinamide, rat, gastrointestinal tract.
Neuropathy affecting alimentary function is a common complication of diabetes. Gastric neuropathy may lead to impairment of gastric emptying [1] and vagally-mediated gastric acid secretion [2]. Incompletely understood damage to the innervation of the gut may lead either to constipation [3] or to faecal incontinence [4]. The pathogenesis of diabetic neuropathy has been studied extensively in the streptozotocin (STZ)-treated rat, a model of insulin-dependent diabetes. Changes in the adrenergic and cholinergic innervation of the colon [5] and bladder [6], in the cholinergic innervation of the heart [7] and in the noradrenergic innervation of the vas deferens [8] have been demonstrated in the diabetic animals. In another recent study [9], signs of degeneration of adrenergic and serotoninergic nerves in the myenteric plexus of the ileum were observed in rats 8 weeks after induction of diabetes. In addition to nerves containing the "classical" neurotransmitters, the gastrointestinal tract is associated with an extensive system of intrinsic and extrinsic peptide-containing neurones [10-12]. In this study, the effects of STZ-induced diabetes of 10 weeks' duration upon the somatostatin, substance $P$ and vasoactive intestinal polypeptide (VIP) content of the stomach and small intestine were quantified using radioimmunoassay. The diabetogenic effect of STZ may be prevented by prior injection of nicotinamide, an inhibitor of poly (ADP-ribose) synthetase, in the B cell
[13]. Consequently, to identify possible non-specific toxic effect of STZ upon peptidergic nerves, the diabetic rats were compared with a control group receiving STZ and nicotinamide as well as with a group receiving saline only.

\section{Materials and methods}

STZ was supplied by Calbiochem-Behring Corporation, La Jolla, California, USA (Lot No.801237) and nicotinamide by Merck, Darmstadt, FRG.

Male Wistar rats (aged approximately 3 months, weight 200 $220 \mathrm{~g}$ ) were fasted for $16 \mathrm{~h}$ and divided into three groups: group A $(n=14)$ received intravenous STZ $(65 \mathrm{mg} / \mathrm{kg}$ dissolved in citrate-saline buffer, $\mathrm{pH} 4.5 ; 0.8 \mathrm{ml})$, group $\mathrm{B}(n=8)$ received intraperitoneal nicotinamide $(500 \mathrm{mg} / \mathrm{kg}) 15 \mathrm{~min}$ before intravenous STZ $(65 \mathrm{mg} / \mathrm{kg})$ and group C $(n=8)$ received intravenous citrate-saline buffer $(0.8 \mathrm{ml})$ only. The animals were housed in metabolic cages and the volume and glucose concentration of urine collected over a 24 -h period was measured periodically. All animals had free access to a standard laboratory diet and water and were weighed at weekly intervals.

Ten weeks after the injections, the animals were fasted for $16 \mathrm{~h}$ and sacrificed by guillotine. A blood sample was taken at the time of sacrifice for blood glucose determination. The entire stomach and small intestine were removed from the animals, washed with isotonic saline and immediately frozen on dry-ice. The small intestine was divided into duodenum (between the pylorus and ligament of Treitz), ileum (terminal $10 \mathrm{~cm}$ ) and jejunum (remaining region). The tissues were weighed and stored at $-70^{\circ} \mathrm{C}$ until time of extraction. 


\section{Tissue extraction}

Tissues were extracted without pre-thawing by boiling for $5 \mathrm{~min}$ in $0.5 \mathrm{~mol} / 1$ acetic acid ( $8 \mathrm{ml} / \mathrm{g}$ tissue) followed by homogenization using an Ultraturrax Blender (Janke and Kunkel GmbH, Staufen, FRG) [16]. The homogenates were centrifuged at $1600 \mathrm{~g}$ for $30 \mathrm{~min}$ and the supernatants lyophilised. The extracts were redissolved in radioimmunoassay buffer $(0.05 \mathrm{~mol} / 1$ sodium phosphate, $\mathrm{pH} 7.4)$ and assayed at appropriate dilution.

\section{Radioimmunoassays}

Somatostatin-like immunoreactivity was measured with an antibody directed towards the central residues of somatostatin-14 that crossreacts with somatostatin-28 [14]. Substance P-like immunoreactivity was measured with an antibody directed towards the $\mathrm{C}$-terminal residues of substance P [15]. VIP-like immunoreactivity was measured using antiserum G-143 that shows no detectable cross-reactivity with glucagon, secretin, gastric inhibitory polypeptide (GIP), peptide histidine isoleucine (PHI) and the [16-28] C-terminal fragment of VIP [16].

\section{Statistical analysis}

All values are given as mean $\pm \mathrm{SD}$. Comparisons between the three groups are made using analysis of variance and between pairs of group using Student's test for unpaired data. Statistical significance is taken as $p<0.05$.

Table 1. Effects of streptozotocin-induced diabetes on the weight of the digestive organs of rats

\begin{tabular}{lcll}
\hline & \multicolumn{2}{l}{ Weight $(\mathrm{g})$} & \\
\cline { 2 - 4 } & $\begin{array}{l}\text { Group A } \\
\text { (STZ) }\end{array}$ & $\begin{array}{l}\text { Group B } \\
\text { (STZ }+ \\
\text { nicotinamide) }\end{array}$ & $\begin{array}{l}\text { Group C } \\
\text { (saline only) }\end{array}$ \\
\hline Stomach & $1.9 \pm 0.3$ & $1.7 \pm 0.2$ & $1.7 \pm 0.2$ \\
Small intestine & $10.7 \pm 1.0$ & $6.4 \pm 0.9^{\mathrm{a}}$ & $6.5 \pm 1.0^{\mathrm{a}}$ \\
\hline
\end{tabular}

Results expressed as mean $\pm \mathrm{SD}$. ${ }^{a} p<0.05$ versus group $\mathrm{A}$

\section{Results}

\section{Development of the diabetic state}

Rats receiving STZ-nicotinamide (group B) and saline only (group $\mathrm{C}$ ) gained weight throughout the experiment (final weights group B: $330 \pm 35 \mathrm{~g}$; group C $314 \pm$ $45 \mathrm{~g}$ ). Rats receiving STZ (group A) underwent a loss in weight during the first 2 weeks and this weight loss was maintained throughout the experiment (final weight $196 \pm 22 \mathrm{~g}$ ). Two days after injection, the 24 -h urine volumes in the diabetic rats $(62 \pm 14 \mathrm{ml})$ were significantly greater than in group B $(8.4 \pm 1.8 \mathrm{ml})$ and group C $(7.4 \pm 3.4 \mathrm{ml})$ rats. Glucose was detected only in the urine of group A rats (Keto-diastix, Ames, Frankfurt, FRG). Polyuria and glucosuria were maintained throughout the experiment. The fasting blood glucose at the time of sacrifice was significantly higher in the group A $(18.0 \pm 3.9 \mathrm{mmol} / 1)$ than in group B (4.6士 $0.4 \mathrm{mmol} / \mathrm{l})$ and group $\mathrm{C}(5.2 \pm 0.8 \mathrm{mmol} / \mathrm{l})$.

\section{Concentrations of regulatory peptides in tissues}

The weights of the digestive organs in the diabetic rats were appreciably different from the corresponding weights in both control groups (Table 1). In particular, a significant increase in the total weight of the small intestine in group $\mathrm{A}$ rats relative to groups $\mathrm{B}$ and $\mathrm{C}$ was observed $(p<0.05)$. An increase in the weights of the stomachs of the diabetic rats was not significant. In consequence, the regulatory peptides in the tissues are expressed both as pmol/g wet weight and as pmol/organ. The small intestine is regarded as a single organ because of uncertainty in the precise delineation of its constituent regions. The data in Table 2 and 3 demonstrate that

Table 2. Effects of streptozotocin-induced diabetes on concentrations of regulatory peptides in rat stomach

\begin{tabular}{|c|c|c|c|c|c|c|}
\hline & \multicolumn{2}{|l|}{$\begin{array}{l}\text { Group A } \\
\text { (STZ) }\end{array}$} & \multicolumn{2}{|c|}{$\begin{array}{l}\text { Group B } \\
\text { (STZ+ nicotinamide) }\end{array}$} & \multicolumn{2}{|c|}{$\begin{array}{l}\text { Group C } \\
\text { (saline only) }\end{array}$} \\
\hline & $\mathrm{pmol} / \mathrm{g}$ & pmol/organ & $\mathrm{pmol} / \mathrm{g}$ & pmol/organ & $\mathrm{pmol} / \mathrm{g}$ & pmol/organ \\
\hline Substance P & $24 \pm 6$ & $45 \pm 14$ & $44 \pm 7^{\mathrm{a}}$ & $72 \pm 8^{a}$ & $35 \pm 6^{\mathrm{a}}$ & $58 \pm 11^{\mathrm{a}}$ \\
\hline Somatostatin & $156 \pm 48$ & $283 \pm 50$ & $112 \pm 20^{a}$ & $184 \pm 42^{\mathrm{a}}$ & $113 \pm 37^{a}$ & $183 \pm 60^{\mathrm{a}}$ \\
\hline
\end{tabular}

Results expressed as mean \pm SD. ${ }^{a} p<0.05$ versus group A

Table 3. The effects of streptozotocin-induced diabetes on concentrations of regulatory peptides in rat intestine.

\begin{tabular}{|c|c|c|c|c|c|c|c|c|c|c|c|c|}
\hline & \multicolumn{3}{|c|}{$\begin{array}{l}\text { Duodenum } \\
\text { (pmol/g) }\end{array}$} & \multicolumn{3}{|l|}{$\begin{array}{l}\text { Jejunum } \\
\text { (pmol/g) }\end{array}$} & \multicolumn{3}{|l|}{$\begin{array}{l}\text { Ileum } \\
\text { (pmol/g) }\end{array}$} & \multicolumn{3}{|l|}{$\begin{array}{l}\text { Total gut } \\
(\mathrm{pmol} / \mathrm{g})\end{array}$} \\
\hline & Group A & Group B & Group C & Group A & Group B & Group C & Group A & Group B & Group C & Group A & Group B & Group C \\
\hline Substance P & $17 \pm 7$ & $51 \pm 19^{\mathrm{a}}$ & $39 \pm 8^{a}$ & $16 \pm 4$ & $41 \pm 8^{\mathrm{a}}$ & $42 \pm 9^{a}$ & $33 \pm 5$ & $61 \pm 11^{\mathrm{a}}$ & $58 \pm 15^{\mathrm{a}}$ & $180 \pm 42$ & $27 \dot{8} \pm 40^{\mathrm{a}}$ & $275 \pm 52^{\mathrm{a}}$ \\
\hline Somatostatin & $48 \pm 14$ & $48 \pm 24$ & $40 \pm 22$ & $34 \pm 14$ & $113 \pm 59^{\mathrm{a}}$ & $88 \pm 27^{a}$ & $56 \pm 16$ & $62 \pm 21$ & $54 \pm 24$ & $390 \pm 123$ & $605 \pm 203^{a}$ & $462 \pm 112$ \\
\hline
\end{tabular}

Results expressed as mean $\pm \mathrm{SD}$. ${ }^{a} p<0.05$ versus group $A$ 
STZ-induced diabetes of 10 weeks' duration results in some significant changes in the content of VIP, substance $P$ and somatostatin in the digestive organs of the rat. In the stomachs of the diabetic rats, a significant increase in the somatostatin concentration and significant decrease in the VIP and substance $P$ concentration were observed in comparison to both control groups ( $p<$ 0.05 ). In view of the increased weight of the stomachs from some of the diabetic rats, the differences in total content of VIP between the groups were not significant. An increase in gastric somatostatin following STZ-induced diabetes in rats has been reported previously [17].

The changes in the regulatory peptide concentrations were not uniform throughout the small intestine. In the duodenal and ileal region of the diabetic rats, no change in the concentration of somatostatin was seen but in the jejunum the concentration $(\mathrm{pmol} / \mathrm{g}$ ) was significantly reduced $(p<0.05)$. In view of the marked increase in weight of the small intestine in the diabetic rats, the total content of somatostatin in the gut was significantly lower only when compared to the group B $(p<0.05)$ and not to the group $C$ animals. Similarly, the VIP concentration in the duodenal and jejunal regions was not different in the three groups, but the diabetic state was associated with an increase in the ileal region (33\% versus group B; NS and $100 \%$ versus group C; $p<0.05)$. In terms of the total VIP content of the gut, the diabetic animals had a significantly higher VIP content than both groups of control rats, reflecting again the increased total weight of the gut $(p<0.05)$. The data with respect to the changes in gut substance $\mathrm{P}$ following diabetes were more straightforward. The group $\mathrm{A}$ animals showed a marked decrease in substance $P$ concentrations in each segment of the intestine relative to both control groups and the decreases were significant $(p<$ $0.05)$. The total substance $\mathrm{P}$ content of the gut was significantly reduced to $65 \%$ of both groups B and C ( $p<$ 0.05).

For all parameters measured in this study, there were no significant differences between the group B (STZ-nicotinamide) and group C (saline only) animals. This result suggests that the observed changes in regulatory peptide concentrations did not arise from a nonspecific toxic effect of STZ upon peptidergic neurones or endocrine cells in the gastrointestinal tract.

\section{Discussion}

STZ-induced diabetes in rats results in the development of gastroenteropathy in about $70 \%$ of the animals which then exhibit gastric paresis, small intestinal stasis and diarrhoea [18]. Other studies have demonstrated development of megacolon [19] and delayed small intestinal transit [20]. The present study suggests that changes in the substance $P$ and VIP content of the gastrointestinal tract may contribute to the pathogenesis of impaired motility. In the human bowel, VIP and substance P are restricted to the non-epithelial layers and have been demonstrated exclusively in nerves [12]. In rodents, however, evidence has been presented that substance $\mathrm{P}$ may also be found in mucosal endocrine cells [21]. Peristalsis involves a contraction of circular muscle on the oral side and a relaxation on the anal side. A role for both VIP [22] and substance P [23] in the regulation of the intestinal peristaltic reflex has been postulated. VIP occurs in axons which originate from cell bodies in the myenteric plexus and project in an anal direction to innervate the circular muscle layer [22]. Release of VIP results in relaxation of smooth muscle [24]. Substance Pimmunoreactive fibres emanate from cell bodies in the myenteric and submucous ganglia and also innervate circular and longitudinal smooth muscle. In contrast to VIP, release of substance $P$ provokes contraction of non-vascular smooth muscle and potent stimulatory effects upon the peristaltic reflex have been described [23]. Thus, the increased total content of VIP in the intestine and increased concentration in the terminal ileum together with the decreased content and concentration of substance $\mathrm{P}$ throughout the gastrointestinal tract may both contribute towards the decreased motility observed in the diabetic rats. The finding of increased gut VIP content is consistent with a previous immunohistochemical study in which STZ-treated rats with gastroenteropathy showed increased immunostaining of VIP-ergic nerves in the mucosa, muscle and ganglia of the small intestine [18]. Immunohistochemical studies have also demonstrated changes in the VIP-ergic innervation of the penis in the STZ-treated rat [25] and in impotent man [26].

The present study has confirmed a previous report [17] that STZ-induced diabetes of medium-term duration results in a significant increase in the somatostatin content of the rat stomach. The total content of somatostatin in the small intestine was decreased in the diabetic animals but a considerable variation in the values between individual animals was observed. Gastrointestinal somatostatin has a dual localisation in mucosal D cells and in nerves mainly found in the ganglionic plexuses [11]. The relative contribution of the two components to the overall change in somatostatin content was not investigated. Somatostatin, infused at pharmacological concentrations, has been shown to reduce absorption of glucose and other nutrients by a mechanism that is independent of effects upon intestinal motility [27]. Glucose absorption by the small intestine is increased in STZ-induced diabetes [28] and it is tempting to speculate that somatostatin-deficiency may be one of the factors (along with increased synthesis of carrier sites in the basolateral membrane [28] and a decreased rate of glucose utilization by the intestine [29] that is responsible.

In agreement with previous reports [30], experimentally induced diabetes resulted in appreciable increases in the weights of the digestive organs compared with the control groups. It has been shown that growth is localized primarily to the mucosa [30] and that a decrease in 
DNA synthesis in the intestine of diabetic animals on a restricted diet is compensated for by hyperphagia in animals fed ad libitum [31]. Although this study has shown that the changes in regulatory peptide concentrations are probably not due to a direct toxic effect of STZ upon gastrointestinal neurones and/or cells, the changes may be a consequence of increased food intake rather than of diabetes per se. In this light, it may be premature to consider that the present findings are necessarily relevant to the pathogenesis of gastroenteropathy in man.

Acknowledgements. The work was supported by the Stiftung Volkswagenwerk and Deutsche Forschungsgemeinschaft (Ba 833/1-2).

\section{References}

1. Howland WJ, Drinkard RU (1963) Acute diabetic gastric atony: gastroparesis diabeticorum. JAMA 185: 214-216

2. Hosking DJ, Moody F, Stewart IM, Atkinson M (1975) Vagal impairment of gastric secretion in diabetic autonomic neuropathy. Br Med J 2: $588-590$

3. Battle WM, Snape WJ Jr., Alavi A, Cohen S, Braunstein S (1980) Colonic dysfunction in diabetes mellitus. Gastroenterology 79: 1217-1221

4. Katz LA, Spiro HM (1966) Gastrointestinal manifestations of diabetes. N Engl J Med 275: 1350-1361

5. Schmidt RE, Nelson JS, Johnson EM (1981) Experimental diabetic autonomic neuropathy. Am J Pathol 103: 210-225

6. Lincoln J, Crockett M, Haven AJ, Burnstock G (1984) Rat bladder in the early stages of streptozotocin-induced diabetes: adrenergic and cholinergic innervation. Diabetologia 26: 81-87

7. Rao VS, Vadlamudi V, McNeil JH (1983) Effect of alloxan-and streptozotocin-induced diabetes on isolated rat heart responsiveness to carbachol. J Pharmacol Exp Ther 225: 410-415

8. Tomlinson DR, Gillon KRW, Smith MG (1982) Axonal transport of noradrenaline and noradrenergic transmission in rats with streptozotocin-induced diabetes. Diabetologia 22: 199-204

9. Lincoln J, Bokor JT, Crowe R, Griffith SG, Haven AJ, Burnstock $G$ (1984) Myenteric plexus in streptozotocin-treated rats: neurochemical and histochemical evidence for diabetic neuropathy in the gut. Gastroenterology 86: 654-661

10. Gershon MD, Erde M (1981) The nervous system of the gut. Gastroenterology 80: 1571-1594

11. Schultzberg M, Hökfelt T, Nilsson G, Terenius L, Rehfeld JF, Brown M, Elde R, Goldstein M, Said S (1980) Distribution of peptide- and catecholamine-containing neurons in the gastrointestinal tract of rat and guinea pig: immunohistochemical studies with antisera to substance $P$, vasoactive intestinal polypeptide, enkephalins, somatostatin, gastrin/cholecystokinin, neurotensin and dopamine $\beta$-hydroxylase. Neuroscience 5: 689-744

12. Ferri G-L, Adrian TE, Ghatei MA, O'Shaughnessy DJ, Probert L, Lee YC, Buchan AM, Polak JM, Bloom SR (1983) Tissue localization and relative distribution of regulatory peptides in separated layers from the human bowel. Gastroenterology 84: 777-786

13. Junod A, Lambert AE, Stauffacher W, Renold AE (1969) Diabetogenic action of streptozotocin: relationship of dose to metabolic response. J Clin Invest 48: 2129-2139

14. McIntosh C, Arnold R, Bothe E, Becker H, Köbberling J, Creutzfeldt W (1978) Gastrointestinal somatostatin: extraction and radioimmunoassay in different species. Gut 19: 655-663
15. Conlon JM, Sheehan L (1983) Conversion of substance P to C-terminal fragments in human plasma. Regul Pept 7: 335-345

16. Agoston DV, Ballmann M, Conlon JM, Dowe GHC, Whittaker VP (1985) The isolation of neuropeptide-containing vesicles from the guinea pig ileum. J Neurochem (in press)

17. Patel YC, Cameron DP, Bankier A, Malaisse-Lagae F, Ravazzola M, Studer P, Orci L (1978) Changes in somatostatin concentration in pancreas and other tissues of streptozotocin diabetic rats. Endocrinology 103: 917-923

18. Kishimoto S, Kunita S, Kambara A, Okamoto K, Shimizu S, Yamamoto M, Koh H, Sano K, Kajiyama G, Miyoshi A, Yanaihara $\mathrm{N}$ (1983) VIPergic innervation in the gastrointestinal tract of diabetic rats. Hiroshima J Med Sci 32: 469-478

19. Nelson JS, Lacy PE, Hirshberg GE (1976) Megacolon and autonomic neuropathy in diabetic rats. J Neuropathol Exp Neurol 35: 335

20. Scott LD, Ellis TM (1980) Small intestinal transit and myoelectric activity in diabetic rats. In: Christensen $\mathbf{J}$ (ed) Gastrointestinal motility. Raven Press, New York, pp 395-399

21. Nilsson G, Larsson L-I, Håkanson R, Brodin E, Pernow B, Sundler F (1975) Localization of substance P-like immunoreactivity in mouse gut. Histochemistry 43: 97-99

22. Furness JB, Costa M (1975) Projections of intestinal neurons showing immunoreactivity for vasoactive intestinal polypeptide are consistent with these neurons being enteric inhibitory neurons. Neurosci Lett 15: 199-204

23. Holzer P, Lembeck F (1980) Neurally mediated contraction of ileal longitudinal muscle by substance $P$. Neurosci Lett 17: 101-105

24. Fahrenkrug J, Haglund U, Jodal M, Lundgren O, Olbe L, Schaffalitzky de Muckadell OB (1978) Nervous release of vasoactive intestinal polypeptide in the gastrointestinal tract of cats: possible physiological implications. J Physiol (Lond) 248: 291-305

25. Crowe R, Lincoln J, Blacklay PF, Pryor JP, Lumley JSP, Burnstock $G$ (1983) Vasoactive intestinal polypeptide-like immunoreactive nerves in diabetic penis. A comparison between streptozotocin-treated rats and man. Diabetes 32: 1075-1077

26. Gu J, Polak JM, Lazarides M, Morgan R, Pryor JP, Marangos PJ, Blank MA, Bloom SR (1984) Decrease of vasoactive intestinal polypeptide (VIP) in the penises from impotent men. Lancet 2: 315-317

27. Krejs GJ (1984) Effect of somatostatin and atropine infusion on intestinal transit time and fructose absorption in the perfused human jejunum. Diabetes 33: 548-551

28. Csáky TZ, Fischer E (1981) Intestinal sugar transport in experimental diabetes. Diabetes 30: 568-574

29. Jamal A, Kellett GL (1983) Regulation of mucosal phosphofructokinase in the small intestine of the streptozotocin-diabetic rat. Diabetologia 25: 355-359

30. Schedl HP, Wilson HD (1971) Effects of diabetes on intestinal growth in the rat. J Exp Zool 176: 487-496

31. Nakayama H, Iju M, Nakagawa S (1974) Influence of diet on intestinal cell DNA synthesis in the diabetic rat. Diabetes 23: $793-795$

Received: 23 January 1985

and in revised form: 17 April 1985

Dr. J. M. Conlon

Klinische Arbeitsgruppe der MPG

Goßlerstraße 10d

D-3400 Göttingen

FRG 